\title{
NADZIEJE I STRACONE ZŁUDZENIA. WOJNY BAŁKAŃSKIE W ŚWIETLE TEKSTÓW Z KRĘGU DIMITRIJI ČUPOVSKIEGO I KRSTE P. MISIRKOVA
}

\author{
LILLA MOROZ-GRZELAK
}

\begin{abstract}
Lilla Moroz-Grzelak, Nadzieje i stracone złudzenia. Wojny bałkańskie w świetle tekstów z kręgu Dimitriji Čupovskiego i Krste P. Misirkova (Hopes and lost illusions. Balkan Wars in the light of the texts from the circle Dimitrija Čupovski and Krste P. Misirkov).
\end{abstract}

Balcanica Posnaniensia. Acta et studia, XIX, Poznań 2012, Wydawnictwo Instytutu Historii UAM, pp. 297-308, ISBN 978-83-63-047-17-7, ISSN 0239-4278. Polish text with a summary in English.

Lilla Moroz-Grzelak, Instytut Slawistyki PAN, Warszawa.

Dzieje Bałkanów końca wieku XIX i początku XX w analizach dokonywanych przez historyków sprowadzane są $\mathrm{w}$ istocie do dyskusji w ramach kilku tematów problemowych. Jak zauważyła Biljana Ristovska-Josifovska, koncentrują się one na kwestii działań Imperium Osmańskiego, które zmierzało do zachowania własnej pozycji; starań, jakie podejmowały wielkie siły w celu rozwiązania „kwestii wschodniej” zgodnie z własnymi interesami oraz ruchów niepodległościowych zniewolonych narodów dążących do utworzenia własnych państw ${ }^{1}$. Macedońscy badacze przyjmują, iż koniec XIX wieku i początek nowego stulecia stanowi już drugi etap procesu odrodzeniowego o nasilonej działalności kulturalno-narodowej i rewolucyjnej. Po klęsce powstania ilindenskiego roku 1903 to kultura stała się głównym polem działania inteligencji macedońskiej na emigracji, co w Macedonii zgodnie uznaje się za istotny element procesu odrodzeniowego ${ }^{2}$. Za taki przyjęto aktywność emigrantów w Petersburgu, skupionych w strukturach Słowiańsko-Macedońskiego Narodowego Towarzystwa Naukowo-Literackiego ${ }^{3}$. Najważniejszym dokumentem wskazującym

${ }^{1}$ Б. Ристовска-Јосифовска, Балканските војни и проекциите за Македонија (македонски поглед), „Slavia Meridionalis” 2012, t. 12, s. 93-106.

2 Б. Ристовски, Столетија на македонската свест. Истражувања за културно-националниот развиток, Скопје 2001, s. 9-25.

3 Словеномакедонското национално-просветно друштво „Св. Кирил и Методиј“ (1912-1913). Zob.: Б. Ристовски, Македонската колонија во Петербург како национален ополномоштеник, [w:] Idem, Истоприја на македонската нащија, Скопје 1999, s. 378-477. 
na nurty tej działalności pozostało wydawane po rosyjsku pismo „Makedonskij gołos”, w którym członkowie tzw. „kolonii macedońskiej” prezentowali swe postawy polityczne i dokonywali interpretacji aktualnych wówczas wydarzeń.

Pierwszy numer ukazał się 9 czerwca 1913 roku, a więc w trakcie ,przerwy” pomiędzy pierwsza, a mającą wybuchnąc niebawem, bo w nocy z 29 na 30 czerwca, drugą wojną bałkańską. Ostatni, jedenasty anonsowanego jako miesięcznik pisma ukazał się 20 listopada 1914 roku, już po zakończeniu wojen bałkańskich, po katastrofalnych dla Macedończyków decyzjach kongresu w Bukareszcie i w trakcie trwającej już pierwszej wojny światowej. Poza głównym redaktorem i autorem wielu publikowanych tam tekstów Dimitriją Čupovskim (1878-1940) i jego bratem Nače Dimovem Čupovskim (1876-1916), z pismem współpracowali Rosjanie, emigranci wywodzący się z ziem macedońskich oraz przybysze z innych zakątków Bałkanów. Na jego łamach publikowano dokumenty oficjalne, tj. memoranda, apele i ogłoszenia kolonii macedońskiej w Petersburgu, które sygnowali m.in. G. Konstantinov, G. A. Georgov, P. Božidarski, N. Ugrinovski, D. Peškovski, G. A. Stojanov oraz wiersze okolicznościowe odzwierciedlające liryczne reakcje na wydarzenia okresu wojen bałkańskich.

„Makedonskij gołos” stanowi najbardziej znaczące źródło materiałowe prezentujące macedońską myśl narodową okresu wojen bałkańskich oraz początku I wojny światowej, a jego kreator i główny redaktor Dimitrija Čupovski, jest dziś uznawany w Macedonii za najwybitniejszą postać emigracji tego okresu ${ }^{4}$. Podstawowe tematy, które przewijały się na łamach pisma, koncentrowały się wokół kwestii obrony całości terytorium macedońskiego i dążeń do utworzenia własnego państwa, a zasadzały się na przekonaniu o wspólnotowości Słowiańszczyzny. Čupovski w programowym artykule pierwszego numeru pisma, Македонія и Македониы. Культурно-историшескій обзор Македоніи, wytyczając ramy tematyczne periodyku, nie krył rozczarowania postawą państw słowiańskich, które zajęły ziemie macedońskie, obalając tym samym idee braterstwa etnicznego, jakie miały łączyć Słowian. Kreśląc zarys minionych dziejów Macedończyków i ich wkładu w dziedzictwo cywilizacyjne Europy, zwracał uwagę na nieustające od wieków dążenia sąsiednich państw do zajęcia ich życiowej przestrzeni. Dla ukazania rangi terytorium macedońskiego w przeszłości odnosił się do roli Justyniana Wielkiego, jego prawodawstwa, które 17 marca 545 roku ustanawiało arcybiskupstwo/ archiepiskopat Justiniana Prima w pobliżu Skopje ${ }^{5}$ a jego synodowi nadawało prawa równe z ustanawianymi przez papieża. Jak dowodził autor, Justiniana Prima stało się zalążkiem arcybiskupstwa ochrydzkiego i odgrywało istotną rolę w dziejach całego kraju, a jego znaczenie rosło wraz z rozwojem języka słowiańskiego i ustaleniem alfabetu przez Macedończyków, świętych braci Cyryla

4 Б. Ристовски, Димитрија Чуповски (1878-1940) и Македонското научно-литературно другарство во Петроград, т. 1-2, Скопје 1978.

${ }^{5} \mathrm{Nie}$ jest zadaniem autorki rozpatrywanie, gdzie była zlokalizowana Justiniana Prima, którą Serbowie lokują współcześnie w miejscowości Caričin Grad w okolicach Leskovca w południowej Serbii, a Macedończycy pod Skopjem jako Tauresium - Taor. 
i Metodego ${ }^{6}$. Čupovski twierdził, iż najgorszym wrogiem samodzielnego bytu Słowian zamieszkujących ziemie macedońskie byli nie tureccy barbarzyńcy, ale „,bracia jednego plemienia i jednej wiary", którzy próbowali pozbawić ich nazwy i asymilować za pomocą kultury, stworzonej przez samych Macedończyków. W przekonaniu emigrantów w Rosji, dla Bułgarów i Serbów, ziemie macedońskie stanowiły jedynie „łakomy kąsek", który podzielony na części włączyli do swoich organizmów państwowych. W takiej sytuacji nadzieją i protektorką ludności zamieszkującej ziemie macedońskie mogła pozostać jedynie Rosja. W swoich tekstach Čupovski przypominał o znaczeniu więzów krwi łączących ich z pozostałymi narodami słowiańskimi, kiedy etniczne braterstwo miałoby pozostać ogólną zasadą kierującą polityką ${ }^{7}$. W jego programowym artykule uwidoczniło się przekonanie macedońskiej emigracji w Petersburgu o tymczasowości podjętych decyzji terytorialnych podziału Macedonii przez kraje sąsiednie i nadzieja na pomoc ze strony Słowian austro-węgierskich, chociaż jednak bez gwarancji otrzymania jakiejkolwiek wsparcia (nr 1, s. 12). W takich okolicznościach swe oczekiwania kierowano przede wszystkim do prawosławnej i słowiańskiej Rosji, która już wcześniej okazywała pomoc słowiańskim, wolnym wówczas państwom Serbii, Bułgarii oraz Czarnogórze. Pokonanie Turcji w pierwszej wojnie bałkańskiej, wbrew podjętym postanowieniom mimo wszystko nie pozbawiało złudzeń, że jednak nastapi poprawa sytuacji ludności macedońskiej i dojdzie do utworzenia własnego organizmu państwowego. Źródłem takich opinii emigracji miała być postawa panującego cara Mikołaja, który chroniłby Macedończyków i dyscyplinował inne narody słowiańskie. Tym samym z wysokości rosyjskiego tronu spodziewano się oddziaływania na Serbię i Bułgarię, by pozwoliły Macedończykom uzyskać autonomię i utworzyć własne państwo. Jak twierdzono, postanowienia podjęte w wyniku pierwszej wojny stanowiły jawną niesprawiedliwość wobec ludności macedońskiej, która znosiła turecką niewolę 35 latach dłużej niż pozostałe narody słowiańskich Bałkanów.

Utopijne w swym założeniu przekonanie Čupovskiego, że Rosja pomoże rozwiązać problem macedoński nie ograniczało się jedynie do tekstu programowego pisma. Na jego łamach pojawiały się zarówno artykuły przywracające zmodyfikowane teorie i plany stworzenia braterskiego związku państw prawosławnych narodów sło-

\footnotetext{
6 „Македонскій голос” 1913, nr 1, s. 7. Tu korzystano z reprintu wydań pisma: Македонскій голос. Орган сторонников независимой Македоніи, Скопје 1968.

7 „Найболее характерной чертой исторіи культурной жизни Македоніи является то обстоятельство, что злейшим врагом их самобытности были не варавары-турки, а свои же братья едноплеменники и едноверцы, пытавшіеця его обезличить и ассимиловать, при помощи культуры, самими же македонцами созданой (...). Южное, балканское, наиболее нам родственное славянство не только не приходило нам на помощ но даже всячески тормозило дела освобожденія Македоніи и терзало ее своими непрерывными культурно-церковными распрями. Эти соседи - славяне глядели на нас и нашу страну, только как лакомый кусок. (...) Другие славянские народы были сами подневольны и никакой помощи, даже если бы и желали - принести не могли. Остается одна Россія - эта покровительница славян. (...) Но что же должно было сделать славянство для своих братьев в Македониіи. Это зависит от каждаго политическаго момента, но общим правилом во все моменты жизни родственных народов должно быть братство”. Zob.: Д. Чуповски, Македонія и Македонцы. Культурно-историшескій обзор Македоніи, „Македонскій голос” 1913, nr 1, s. 10-12.
} 
wiańskiego południa, w których deklarowano nieangażowanie się Macedończyków przeciwko innym Słowianom, jak i teksty, w jakich skarżono się, iż opanowani żądzą powiększenia swych państw Słowianie sami zaprzepaścili wartości wspólnotowe we wzajemnych walkach. W jednym $\mathrm{z}$ artykułów zamieszczonych w pierwszym numerze, Под победной колесницей, jego autor A. Novogradskij przypominając o zawiązaniu się sojuszu czterech państw bałkańskich domagał się od nich właśnie utworzenia niezależnej Macedonii. Jak twierdził, do wybuchu wojny w 1912 roku Serbia i Bułgaria były maleńkimi, nieznaczącymi państwami, których głos nie był słyszalny w Europie. Zmiana ich pozycji i wzrost terytorialny dokonany kosztem ziem macedońskich w przekonaniu autora wymagała rewizji, gdyż tym samym nastapiła zamiana jednej wrogiej siły na trzy inne, które totalnie pogrążyły Macedonię. W kontekście niezgody na przemiany, jakie dokonały się na półwyspie powracał zwykle motyw zaufania do słowiańskiej Rosji - ta nieustannie, przez cały okres ukazywania się pisma stanowiła dla emigrantów jedyną nadzieją na zapewnienie słowiańskiej „zdeptanej” Macedonii autonomii i była gwarantem pokoju w południowej Słowiańszczyźnie (nr 1, s. 14-15). Mimo decyzji, jaka zapadła kilka miesięcy wcześniej w Londynie o rozczłonkowaniu Macedonii, redakcja pisma zamieściła w czerwcowym numerze, w przeddzień wybuchu drugiej wojny bałkańskiej, Memorandum podpisane 1 marca 1913 roku i skierowane do wielkich sił. Przypominano w nim, że zgubne decyzje kongresu berlińskiego, które choć dawały autonomię Bułgarii, zmieniały status Serbii i przebudowały porządek na Półwyspie Bałkańskim, to jednak doprowadziły do wywołania napawającej lękiem kwestii macedońskiej. Pokonanie Turcji w pierwszej wojnie, choć było dla jego autorów wyzwoleniem spod pięćsetletniego panowania tureckiego, to jednak nie rozwiązywało problemu słowiańskich mieszkańców Macedonii. Podział ich terytorium pomiędzy Bułgarię, Grecję i Serbię stał się naruszeniem historycznych praw ludności do własnego państwa, w sytuacji, kiedy $2 / 3$ jej ludności stanowili Słowianie. Jak sygnalizowano, inne etnosy zamieszkujące Macedonię, Albańczycy, Arumuni, Grecy i Żydzi w ramach tego potencjalnego bytu państwowego dla harmonijnego rozwoju miałyby być zrównane w prawach. Podnoszonym argumentem przemawiającym na korzyść wypełnienia dwóch sprecyzowanych w dokumencie postulatów, czyli zapewnienia swobodnego rozwoju całości ziem macedońskich, jako jednego organizmu politycznego i zarząadzenia w Salonikach głosowania Macedończyków w celu wskazania kształtu przyszłego państwa, miał być udział macedońskich czetników w pierwszej wojnie z Turcją i decydująca rola, jaką odegrali oni podczas krwawej bitwy pod Kumanovem ${ }^{8}$.

Kwestię działań sąsiednich narodów poruszano w większości materiałów publikowanych po rosyjsku w trakcie obu wojen. Dowodzono, iż stały one w sprzeczności z podstawowym celem, jakim miało być samodzielne państwo. Bułgarom wytykano błędy w traktowaniu Macedończyków, dowodzono ich „,przestępczego wręcz charakteru" i zarzucano zdradę słowiańskich interesów, gdyż, jak twierdzono, to wła-

\footnotetext{
${ }^{8}$ Меморандум о независимости Мекедоніи, „Македонскій голос” 1913, nr 1, s. 21-23.
} 
śnie Bułgaria doprowadziła do rywalizacji o przywództwo9. Wiara w moc Rosji ciagle uznawanej zaś najważniejszego członka słowiańskiej rodziny, który mógłby uratować Macedonię przed ostatecznym rozdrobnieniem ${ }^{10}$ podlegała drobnym modyfikacjom w dalszych numerach pisma. Jednak, jak zauważano sporadycznie, także oczekiwania wobec Rosji okazywały się bezpodstawne, gdyż i ona nie pospieszyła na czas ze wsparciem w rozwiązaniu kwestii macedońskiej. Stało się to powodem do przywrócenia metafory - „dziadek Iwan” ${ }^{11}$ - sygnalizującej z jednej strony szacunek i bojaźń wobec Rosji, z drugiej zaś starszeństwo, które pozwalało żywić nadzieję na wsparcie w potrzebie. Jak odnotowała redakcja przy okazji opublikowanego pod tym samym tytułem wiersza, takie określenie wśród Macedończyków przechodziło z pokolenia na pokolenie niosąc ze sobą przesłanie, iż „dziadek Iwan” uratuje maleńką Macedonię przed ekspansjonistycznymi planami zaborczych państw. Nawiązując do mocarstwowej potęgi Rosji, tym samym do jej wyższości względem swego etnosu, autor podpisujący się pseudonimem „Macedończyk”, kierował swe prośby do krewnego, który wcześniej oddał zasługi słowiańskiemu światu, by kontynuował swe dzieło dla „wielkiego braterstwa" pomagając także Macedończykom uzyskać wolność ${ }^{12}$.

Błagalne w swej wymowie prośby, jakie zamieszczano na stronach pisma, osadzano zwykle w kontekście historycznym i geograficznym, co zwykle podkreślało znaczenie ziem macedońskich, wielkich postaci jej historii i przypominało o przynależności do świata Slavia Orthodoxa. Jednak jak zauważał Nače Dimov Čupovski, apele o utworzenie wolnego państwa, nawet jeśli ukazywały Słowian macedońskich jako dzielnych stróżów idei słowiańskich, cerkwi prawosławnej, piśmiennictwa i kultury oraz podejmowały temat ich udziału w walce $\mathrm{z}$ tureckim molochem i z islamem, to jednak pozostawały bez echa ${ }^{13}$. Mimo to emigranci skupieni w Petersburgu nie ustawali w działaniach nakierowanych na realizację postawionego celu formułowanego zwykle, jako autonomia ziem macedońskich. Dowodząc istnienia własnej tradycji narodowej, powoływali się na wielkie postacie wywodzące się z Macedonii, przyjmując je za „silne argumenty historyczne”, które uzasadniać miały prawo do domagania się niezależności terytorialnej i przestrzegać przed podziałem ziem przez braci jednej

9 Д. Чуповски, Што претставуваме Бугарија за Македонија, [w:] Документи за борба на македонскиот народ за самостојност и за нащионална држава, t. 1, ред. Х. Андонов-Полјански, Скопје 1981, s. 575-577.

10 „Верь, македонець, сыны великой Россіи поймуть твою скорбь... они подадуть тебе руку, как много страдавшему брату... Ведь это ихъ долгъ...Братская кровь, совесть и Богъ призываютъ ихъ спасти нашу страну отъ окончательнаго уничтоженія...” Zob.: П. Б., Верь, Македонецьъ, „Македонскій голос” 1913, nr 3, s. 53.

11 Zob.: А. Белимірскій, „, Македонскій голос” 1913, nr 8, s. 139.

12 „Дедо Иване! - светлый спаситель Славянства - /Братьев спасая и нась не забудь.../ Сделай ты дело великаго братства,/ Чтобы мы вышли на радостный путь”. Zob.: Македонецъ, Дедо Иванъ, „Македонскій голос” 1914, nr 11, s. 220.

13 „Но секогаш Македонските Словени си останувале достојни храбри чувари на словенските идеи, на православна црква, на писменоста и култура". Zob.: Документи за борба на македонскиот народ..., t. 1, s. 558. 
krwi i wiary, co ich zdaniem byłoby nie tylko łamaniem praw człowieka, ale przyniosłoby wstyd całej Słowiańszczyźnie ${ }^{14}$.

I choć rezultaty pierwszej wojny ujawniły rozbieżność interesów między walczącymi stronami, w licznych artykułach redaktora pisma i jego współpracowników nie porzucano nadziei na utworzenie własnego państwa i nadal spodziewano się, że przy pomocy Rosji, jej wiążących decyzji, Macedonia stanie się trzecim, obok Serbii i Bułgarii, słowiańskim państwem Bałkanów (nr 1, s. 13).

Argumentem przemawiającym za słusznością dążeń ludności słowiańskiej Macedonii do zachowania autonomii i niepodzielności ziem był przykład rozbioru Polski. Jeden z autorów, K. Popov, w tekście „Балканская освобождительная война и Македонія odniósł się do udziału Macedończyków w wojnie sojuszniczej chrześcijan przeciwko azjatyckiemu wrogowi czyli Turcji. Ten fakt, $\mathrm{w}$ jego przekonaniu, powinien był zapewnić Macedonii terytorialną niepodzielność, by nie doszło do powtórzenia historycznego błędu, jakim był niegdyś podział państwa polskiego ${ }^{15}$. Do tego samego wątku - rozbiorów Polski - powracano także w kolejnych numerach pisma, przytaczając artykuły z polskich gazet o sytuacji Macedonii i krzywdzących ją decyzji pokojowych, które utrwalały podział ziem. W celu unaocznienia dramatycznej sytuacji nazywano Macedonię „,bałkańską Polską”, przypominając, że w przeszłości dokonano rozparcelowania tego kraju przez sąsiadów ${ }^{16}$. Mimo to Polacy, jak pisano w artykule Польская, podobnie, jak w wojnach bałkańskich Macedończycy, kładli głowy walcząc $w$ interesach innych państw i narodów, i podobnie jak Polacy znaleźli się w granicach trzech obcych państw. Opierając się na przykładzie polityki germanizacyjnej wobec Polaków, wskazywano na groźbę niszczenia macedońskich obyczajów, języka i kultury w państwach zaborczych, które wobec Macedończyków zaczęli stosować już i Grecy, i Serbowie. Decyzje europejskiej dyplomacji o rozbiorze terytorium macedońskiego pomiędzy państwa bałkańskie traktowano jak kardynalny błąd, który w przyszłości mógłby przynieść eskalację konfliktów przez nawarstwienie problemów i sporów terytorialnych ${ }^{17}$. Aby uniknąć podobnej decyzji emigranci wychodzili z propozycją utworzenia braterskiego związku państw słowiańskich, który miałby stanowić przeciwwagę dla ekspansjonizmu obcych. Wbrew decyzjom, jakie już zapadały, wzywali do wspólnego dzieła i utworzenia związku bałkańskiego, być może, jak twierdzono, nawet czysto południowosłowiańskiego (Serbia, Czarnogóra, Bułgaria i Macedonia), który jednoczyłby w swej polityce wszystkie narody słowiań-

14 Меморандум, „Македонскій голос” 1913, nr 1, s. 21-23.

15 К. Попов, Балканская освободительная война и Македонія, „Македонскій голос” 1913, nr 1, s. $15-16$

16 От редакиіи, „Македонскій голос” 1914, nr 10, s. 7.

17 „Европейская дипломатія хочет мира, европейская дипломатія пуще огня. Боится всякаго родо волненія и она же, своим злочатным решеніем - оставит Македонію во власти балканских государств - создала надолго (до полнаго освобожденія или полнаго уничтоженія македонскаго народа) очаг революціи из Македоніи... Дипломатія поступила "дипломатично", но забыла непреложную истину: „Посеявшй бетер - пожнет, бурю”, Zob.: Польская, „Македонскій голос” 1913, nr 5, s. 96. 
skie z polityką wielkiej Rosji pod uznanym za naczelne dla Macedończyków hasłem „Wolności i braterstwa słowiańskiego"18. Rozczarowanie postawą bliskich etnicznie narodów, kiedy stanowisko Bułgarii i Serbii nie pozostawiało już złudzeń, co do „słowiańskiego braterstwa”, odzwierciedlano w licznych artykułach i wierszach, m. in.: Македониь къ братьям славянамъ ${ }^{19}$, сzу Передъ борьбой ${ }^{20}$. Zwracano w nich uwagę, iż to właśnie nazywane „braćmi” inne narody słowiańskie nie pozwoliły Macedończykom doczekać uzyskania wolności i niezależności.

Sytuacja po zakończeniu wojen bałkańskich, mimo rozgoryczenia postawą sąsiednich państw nadal była okazją do manifestowania własnej niezależności i znowu Nače Dimov Čupovski odwoływał się do macedońskiego dziedzictwa, wkładu Macedończyków w rozwój kultury całej Słowiańszczyzny poprzez działalność Cyryla i Metodego i wskazywał na poczucie macedońskiej odrębności narodowej wbrew twierdzeniom bułgarskim, serbskim i greckim, że ludność podzielonego terytorium macedońskiego to Serbowie, Bułgarzy czy Grecy ${ }^{21}$.

Argumenty odwołujące się do tradycji własnych bohaterów, jak wiadomo nie odniosły pożądanego skutku - w wyniku działań europejskiej dyplomacji, na mocy traktatu podpisanego 10 sierpnia 1913 roku w Bukareszcie usankcjonowano podział Macedonii na trzy części22 ${ }^{22}$ I jeszcze wtedy, po zakończeniu wojen bałkańskich, mimo niekorzystnych dla nich postanowień konferencji pokojowej nie porzucali nadziei na możliwość przywrócenia jedności swego terytorium pod egidą Rosji. Teraz jednak, znowu pod hasłami wspólnoty wszystkich Słowian, kierowano apel do wszystkich chrześcijańskich Słowian, К нашим братям! i ponownie przypominano macedońskie zasługi w dziedzictwie kulturowym Europy oraz rangę Cyryla i Metodego, a za przykładem Polaków pozbawionych własnego państwa, nawoływano do wspólnej walki pod wodzą cara przeciwko zbliżającemu się germańskiemu zagrożeniu ${ }^{23}$. Niebezpieczeństwo

18 „Македонцы хотятъ свободы, добиваются ея и получать, но никогда не стануть ценою своей свободы орудіемъ направленнымъ противъ славянъ Сербовъ и Болгаръ. Свободная Македонія хочетъ жить въ тесномъ братстве и единеніи со своими славянскими соседями, и, становясь независимой, она будетъ настаивать на возсозданіи Балканскаго союза, можеть быть, даже чисто южнославянскаго (Сербія, Черногорія, Болгарія и Македонія), соединяющаго свою политику съ политикой великой Россіи, въ которомъ Македонія будетъ вернымъ и силнымъ членомъ. „Свобода и славянское братство” - вотъ девизъ македонцевъ”. Zob.: Чего хотятъ Македонияь ?, „Македонскій голос" 1913, nr 3, s. 42.

19 „Не турок тут дрался на смерть съ славяниномь,/ Не швабы Шар-Дагъ перешли.../Болгары и сербы в забвеньи звериномъ, /Делить македонца пошли”. Zob.: Г. C., Македониы къ братьям славянамъ, „Македонскій голос” 1913, nr 10, s. 21.

20 Передъ борьбой, „Македонскій голос" 1914, nr 9 , s. 2.

21 „Вчерашни среќни сојузници, браќа по крв, сега се свирепи дзверови, непријатели во жестоки судири еден со други се мачат, тепат, убијат (...). Кого од нас Македонците, не нѐ уверувале дека сме ту Бугари, ту Срби, ту Грци, туку сме одделен народ со свое споствено име - Словеномакедонци. Ние сме народ - потомок на некогашни славни предци кои во лицето на великите браќа Кирил и Методиј му дале светлина и висина на целото Словенство”. Zob.: Документи за борба..., t. 1, s. 568-569.

22 I. Stawowy-Kawka, Historia Macedonii, Wrocław-Warszawa-Kraków 2000, s. 169.

${ }^{23}$ К нашим братям!, „Македонскій голос” 1914, nr 10, s. 6-7. 
wybuchu wielkiej wojny przyniosło kolejne teksty, które pisane pod wpływem carskich apeli kierowanych do „braci Słowian” o zjednoczenie się w walce przeciwko Austro-Węgrom, utożsamianym z niemieckim zagrożeniem, spotkało się z przychylnym odzewem macedońskich emigrantów i znowu niosło nadzieję na uzyskanie własnej państwowości w przyszłości. Tym razem już nie grecka hierarchia kościelna, już nie Turcja, ale Niemcy stanowiły niebezpieczeństwo nie tylko dla ludności macedońskiej, ale także dla wszystkich Słowian. Postrzegając możliwość zmiany statusu swoich ziem, emigranci skupieni w Petersburgu wystosowali wówczas własny apel Пойдемъ къ славянской победе, kierowany do Macedończyków o uczestnictwo w wojnie przeciwko Germanom. Powoływano się w nim na istnienie wspólnoty słowiańskiej, która nie była już określana w kategoriach związków braterstwa. Autorzy nawoływali do pozostawienia na uboczu wszelkich rozgrywek międzysłowiańskich w obliczu takiego zagrożenia ekspansją. Skonsolidowanie wysiłków, jak twierdzono w apelu, pozwoliłoby na oparcie się zaborczym planom uznanego za „cywilizowanego” zdobywcy - tak by nie doszło do zniknięcia z powierzchni ziemi plemienia słowiańskiego, na kościach, którego powstała współczesna potęga germańska ${ }^{24}$.

Dramatyczne dla działaczy macedońskich wydarzenia wokół wojen lat 1912-1913 i ich skutki w odmiennej tonacji zostały ukazane w dziennikach Krste Petkova Misirkova (1874-1926). Uznany współcześnie przez Macedończyków za „najżarliwszego prawdziwego macedonistę" o zasługach niepodważalnych dla swego kra$\mathrm{ju}^{25}$ inaczej niż członkowie kolonii macedońskiej $\mathrm{w}$ Petersburgu postrzegał rolę Rosji. Znamienna jest w jego przypadku ewolucja poglądów, kiedy jeszcze 1903 roku, w epokowym i ,prometejskim"26 dla nich dziele 3 а македониките работи podawał $\mathrm{w}$ wątpliwość istnienie braterstwa słowiańskiego z sąsiednimi narodami, ale wskazywał na możliwości narodu macedońskiego i utworzenie własnego państwa przy pomocy prawosławnej i słowiańskiej Rosji. Wojny bałkańskie wydają się jednak uzasadniać zmianę wcześniejszych narodowotwórczych pomysłów, jakie prezentował dziesięć lat wcześniej. Jego postawa uległa zauważalnemu procesowi przemian $\mathrm{w}$ związku z nową sytuacją geopolityczną ${ }^{27}$, a świadczy o tym prowadzony

24 „И мы, македонцы, должны понять высокое значеніе настоящей исторической минуты и согласиться съ темъ, что сейчасъ передъ нами, какъ самымъ древнимъ славянскимъ племенемъ, изъ недръ котораго вышли славянскіе первоучители св. св. Кириллъ и Мефодій и первые зачатки нашей славянской культуры, стоитъ задача, не отказываясь отъ нашихъ частных стремленій, ныне же перейти къ цели общей всему славянству, примкнуть къ борьбе главной съ тевтонскимъ врагом”. Zob.: Пойдемъ къ славянской победе, „Македонскій голос” 1914, nr 10, s. 9-10.

25 „најогнениот вистински македонист”. Zob.: Г. Сталев, Историја на македонската книжевност, II дел, Прва половина на 20. век, Скопје 2003, s. 36.

26 Г. Старделов, Една прометејска книга. К.П. Мисирков „,За македонияките работи” 1903-1998, [w:] Свечен собир по повод 95-годишнината од излегувањето на делото „, За македониките работи” и 5-годишнината од смртта на акедемик Блаже Конески, ред. Т. Георгиевски, К. Фидановски, Скопје 1999, s. 21-35.

27 Zdaniem Alexandra Maxwella, Misirkov już w 1907 roku przyjmował, że w rywalizacji o ziemie macedońskie między Bułgarią a Serbią Słowianie macedońscy mogliby znaleźć się w państwie buł- 
Дневник ${ }^{28}$, gdzie Misirkov deklarował się już nie jako Macedończyk, ale jako Bułgar macedoński, powracając tym samym do wyznacznika terytorialnej tożsamości, jakim określano Słowian wywodzących się z terenów Macedonii w okresie przed kongresem berlińskim.

Dziennik obejmuje wpisy dokonane w okresie niespełna dwóch miesięcy - od 5 lipca do 30 sierpnia 1913 roku, a więc w rozstrzygającym dla losów Macedonii okresie, kiedy zwolennicy autonomii poszukiwali różnych sposobów na zachowanie jej terytorialnej jedności. Odrzucając związki wspólnotowe z Serbią i Grecją, jako sąsiadami, widział je w bliskości z Bułgarią i dlatego w obliczu zatwierdzenia podziału terytorium przez sąsiadujące z nią państwa przyznawał jej prawo do całej Macedonii, w niej upatrując gwaranta terytorialnej jedności ${ }^{29}$. Notatki z poszczególnych dni przed kongresem w Bukareszcie prowadzone przez Misirkova wskazują nie tylko zmianę jego stanowiska i przyjęcie opcji probułgarskiej. Pozostają one przede wszystkim głównym materiałem oskarżycielskim wobec polityki prowadzonej przez Rosję na Bałkanach pod pozorem idei wspólnoty słowiańskiej. Zmianę stosunku do Rosji usprawiedliwiać miały dziesięcioletnie obserwacje poczynione w trakcie jego pobytu w tym państwie, kiedy ostatecznie rozczarował się do rosyjskiego sposobu życia i stracił zaufanie do ideowości i „humanitarnego” obrazu rosyjskiej polityki zagranicznej. Przy takim stanowisku nakreślił nowe rozumienie sojuszu z Rosją, dla której Bułgaria mogłaby stać się równorzędnym partnerem. Powodem przyjęcia takiej postawy były niekwestionowane, w jego przekonaniu, zasługi Bułgarów w wypędzeniu i rozgromieniu Turków w trakcie pierwszej wojny bałkańskiej. Jak zanotował na stronach swego dziennika Misirkov, konsekwencje, zamiast należnego Bułgarii szacunku za odniesione wówczas zwycięstwa, pozostały opłakane. Winą za ten stan rzeczy obciążył Rosję, która w jego odbiorze obawiała się rosnącej potęgi państwa bułgarskiego, a swą politykę na Bałkanach rozgrywała kosztem Bułgarii. Stał na stanowisku, że Macedonia wobec Bułgarii stanowi problem podobny do tego, jak relacje Polski wobec Małorusi, którą Polacy władali z górą lat 300. Nie znajdował uzasadnienia dla polityki Serbii, która zajęła ziemie macedońskie powołując się na dziedzictwo swego państwa na tym terytorium - według Misirkova było to ledwie trzydziestoletnie pano-

garskim. Zob.: A. Maxwell, Slavic Macedonian Nationalism: from „,Regional” to „Ethnic”, “Ethnologia Balkanica” 2007, vol. 11, s. 139.

28 К. П. Мисирков, Дневник. 5 јули-30 авгусm 1913 г., red. 3. Тодоровски, Ц. Билјарски, Скопје 2008. Tu korzystano z wydania udostępnionego w Internecie. Zob.: http://mk.wikipedia.org/wiki/Dnevnik - dostęp wrzesień 2012.

29 Publikacja wydana we współpracy macedońsko-bułgarskiej sprowokowała liczne spory koncentrujące się głównie wokół sposobu określania się Misirkova jako Bułgara macedońskiego. W dyskusjach, jakie rozgorzały po opublikowaniu dziennika, krytykujących jego ujawnienie, był to najczęściej podnoszony wątek, który przyćmił zdecydowanie antyrosyjską i antysłowiańską wymowę tekstu. Przeciwnicy druku twierdzili nawet, iż dziennik przyczynia się do szerzenia antymacedońskiej doktryny i narusza fundamenty macedońskiej tożsamości narodowej. Zob.: В. Цветаноски, Непознатиот Мисирков меѓу Македониите, „Утрински весник” 2008, nr 2686. 
wanie serbskie w XIV wieku ${ }^{30}$ - tym samym, jak twierdził, Macedonia powinna zostać w granicach Bułgarii, albo nie powinna należeć do nikogo, czyli pozostać niezależnym państwem ${ }^{31}$.

Podobnie, jak autorzy wydawanego w Petersburgu pisma, tak i Misirkov dla unaocznienia problemu bułgarskiego i podziału terytorium macedońskiego odwoływał się do rozbiorów słowiańskiej Polski ${ }^{32}$. Co więcej, zmieniwszy swoje pozycje ideowe twierdził, iż to polityka Rosji doprowadziła do wykreowania po kongresie berlińskim nowego narodu na Bałkanach kosztem Bułgarii dając możliwość szerzeniu się serbskiej propagandy na terenie Macedonii ${ }^{33}$. Prowadzenie takiej polityki umożliwiała największemu słowiańskiemu państwu Europy ideologia wspólnoty słowiańskiej, pod której przykrywką Rosja uzależniała od siebie inne słowiańskie państwa i narody $^{34}$. Jak zapisał 8 lipca 1913 ta właśnie polityka przyniosła Bułgarom więcej szkód, niż dobra polityka z okresu kongresu berlińskiego, czyniąc Bułgarów i Rosjan nieprzyjaciółmi. W takiej sytuacji nawoływania Rosji do utworzenia bałkańskiego sojuszu uważał za sprzeczne z interesami Bułgarii, gdyż byłby on potrzebny Rosji jedynie do stworzenia milionowej armii, która mogłaby walczyć z Austrią ${ }^{35}$. Natomiast działania prowadzone przez Rosję na Bałkanach wiodłyby do stworzenia na tych ziemiach rosyjskiego protektoratu (9.07), gdy potencjalna klęska Austrii stałaby się porażką nie tylko południowej Słowiańszczyzny, ale całej cywilizacji zachodniej Europy nad

30 „Едно прашање претставува пробен камен во односите на Русија кон Бугарија. Тоа е македонското прашање. Јасно е дека Македонија за Бугарија е исто што и Малорусија. Ако Русија, без оглед на тоа што Полска владеела во Малорусија 300 години, сепак ја побарала и ја зела од Полска, уште повеке Бугарија има право на Македонија, во која во XIV век Србите владееле само 30 години”. Zapiski z dn. 12.07.1913.

31 „Македонија или треба да биде бугарска, или ничија, т. е. независна држава”, op. cit.

32 „Тие веќ ја извршија првата поделба на Бугарија и можеби сметаат дека таа ке се премисли, ќе се помири со својата положба за да ја избегне втората и третата поделба. Сепак, колку словенската историја ги сака поделбите. Во XVIII век овој експеримент го применија на словенска Полска. Во поделбата на Полска учествуваа словенска Русија и две несловенски држави - Германија и Австрија. Русите велат дека за првата поделба бил виновен Фридрих Велики. Во првата поделба на Бугарија иницијативата и раководната улога ја има словенска Србија под покровителство на Русија. Полска, велат, ја уништила внатрешната анархија. Бугарија, веројатно, ја уништиле нејзините воени успеси во војната со Турците. Од Бугарите се исплашиле како од ривали за владеењето во протоците”.

33 „Русија го наруши политичкото единство на бугарскиот народ, и ја даде Босна и Херцеговина на Австрија, како одмазда за стремежот на Кнежеството Бугарија за ослободувањето од руското старателство почна да ја покровителствува српската пропаганда во Македонија, каде што руските конзули во текот на 35 години беа вистински погребувачи на бугарската народност и подготвуваа почва за поделба на Македонија мегу Србија и Грција”. Ibidem.

34 „Грубите методи што ги користи руското словенофилство при насочувањето на словенските потоци во руското море најјасно од се се покажаа во поразот и поделбата на Бугарија по наговор и покровителство на Русија. (...) Кутрото Словенство! Колку си жално! Колку го засмејуваш светот со својата политичка незрелост и варварска жестокост и со насилството врз сопствените браќа”. Ibidem.

35 „Балканскиот сојуз ѝ е потребен на Русија и таа се бори за негова реализација по секоја цена. Тој сојуз ке ѝ даде на Русија милионска армија за борба со Австрија, но што ѝ е гајле на Русија дека Бугарите немаат апсолутно никакви интереси во Австрија, и според тоа нема зошто да им помагаат на соседите што ги ограбија". Zapiski z dnia 8.07.1913.. 
Wschodem, czyli Rosją ${ }^{36}$. Podział Bułgarii, aneksja terytorialna części zdobyczy bułgarskich stawiały ją tym samym w roli ofiary w służbie idei słowiańskiej, którą lansowała Rosja ${ }^{37}$. Druga wojna bałkańska pomiędzy sojusznikami była więc nie tylko wojną bratobójczą, ale poważną lekcją polityczną nawiedzonych idealistów słowiańskich, w sytuacji kiedy powinno nastąpić zjednoczenie Macedonii i Bułgarii ze względu na pokrewieństwo krwi i tę samą wiarę ${ }^{38}$. O tym jak bliscy są sobie Macedończycy i Bułgarzy poświadczać by miały lata potencjalnego spokoju w Bułgarii, którą zasilił napływ emigrantów z ziem macedońskich opanowanych przez Serbów i Greków, przyczyniając się do wzmocnienia kulturalnej i politycznej siły Bułgarii ${ }^{39}$.

Dwa zaprezentowane stanowiska, odmienne w swej wymowie wynikały, więc, z dwóch różnych podejść do idei wspólnoty w łonie Słowiańszczyzny propagowanej przez Rosję oraz stosunku do samej Rosji. Dla kolonii macedońskiej w Petersburgu, która korzystała z rosyjskiej gościnności uzasadnione były nadzieje na poprawę statusu Słowian macedońskich za jej pomocą. Umiejętnie wykorzystywana przez Rosję w polityce zagranicznej idea wspólnoty słowiańskiej mimo zaistniałych okoliczności i decyzji o podziale ich ziem podtrzymywała skutecznie wiarę w urzeczywistnienie macedońskiej autonomii w przyszłości. Probułgarskie nastawienie Misirkova, całkowicie pozbawionego złudzeń, co do działań politycznych słowiańskiego mocarstwa, nie tylko obnażały fikcje wspólnoty etnicznej, ale postrzegały ją jak narzędzie Rosji do podporządkowania sobie mniejszych narodów słowiańskich i usprawiedliwiania rosyjskiej ekspansji na ich ziemie.

36 „Поразот на Австрија би бил пораз не само на целото западно и јужно Словенство, туку и пораз на Западна Европа. Триумфот на Русија би значела победа на помалку културниот Исток над покултурниот Запад. Впрочем, таквата победа би била привремена, бидејки ширењето на Русија кон Запад внатре во земјата". 9.07.1913.

37 „Поделбата на Бугарија претставува жртва на бугарскиот народза интересите на Словенството и западноевропската култура. Во среден век Бугарија ја штитеше Западна Европа од нападите на неточните народи, во XX век бугарскиот народ исто така застана на страната на политичките принципи на Западна Европа против стремежите на неточната голема држава за утврдување на светска монархија, во која би била погребана западната цивилизација. Државите на Тројниот сојуз ја сфакаат улогата на Бугарија и правилно ја оценија нејзината вредност. Дали ке успеат да ги заштитат нејзините интереси, ке покаже блиската иднина. Англија, изгледа, исто така не се радува многу поради поделбата на Бугарија. Најнеразумен е односот на републиканска Франција, која со својот капитал и со политичката поддршка го подготвува неконтролираното владеење на источниот царизам над Европа". Ibidem

38 Создавањето на голема Бугарија, која ке ѝ биде должна на Русија за: 1 . Ослободувањето во 1878 година, 2. Создавањето автономна Македонија во 1913 година, и 3. Обединувањето на Македонија и Бугарија во иднина, поради крвното сродство и истата вера на Русите и Бугарите, ке биде целосно исполнување на руската ослободителна мисија на Балканот”. Ibidem.

39 „Војната заврши и Бугарија ке почне брзо да заздравува од нејзините последици. Бугарија е спасена во блиска иднина од внатрешните потреси што ке мора да ги издржат Србија и Грција во врека со понатамошниот развој на македонското прашање. Напливот на македонските емигранти само ке ја засили културната и политичката мок на Бугарија". Ibidem. 


\title{
HOPES AND LOST ILLUSIONS. \\ BALKAN WARS IN THE LIGHT OF THE TEXTS \\ FROM THE CIRCLE DIMITRIJA ČUPOVSKI AND KRSTE P. MISIRKOV
}

\begin{abstract}
Summary
This paper addresses the sense of national identity of the Macedonians in the period of the Balkan wars and their aftermath. The first source material were used journalistic texts and calls in the journal „Makedonskij Golos” published by Macedonian expatriates gathered around Dimitrija Čupovski in St. Petersburg in the years 1913-1914. Second was diary (Dnevnik) written by Krste Petkov Misirkov in 1913. Expression of these two major characters in the Macedonian history reflect geopolitical policies conducted in the Slavic population in the Balkans. It is an important source material documenting the national consciousness of intelligence derived from the Macedonian lands. This indicates that the main topics which were then undertaken focused on the defense of the whole Macedonian territory, aspirations to create their own state and diversified approach to the idea of the Slavic community.
\end{abstract}

